\section{Prehistoric Research in South Africa}

IN another column of this issue of Nature (see p. 998) we publish an announcement of action taken by the Government of the Union of South Africa which will play a part of great importance not only in the advancement of the study of the prehistory of the sub-continent, but also ultimately, it may be asserted with confidence, in the elucidation of the whole problem of the distribution and development in culture of early man. The joint geological and archæological survey of certain sections of the Vaal and Riet River valleys, for which arrangements are being made by the Directors of the Geological Survey and the Bureau of Archæology of the Union, will cover an area which in the view of local archæologists, and indeed, as has been shown notably and convincingly by the exploratory work of Prof. C. van Riet Lowe, is of cardinal importance in the correlation of geological and archæological data in South Africa and the determination of their relation to evidence of climatic variation. As the survey will occupy fully the services of two geologists and an archæologist for at least eight months, the undertaking will be costly; but the expenditure is justified, even in present financial conditions, by the fact that this key area will be inundated when the dams now in course of erection across these rivers have been completed.

THE study of the prehistory of South Africa has made great strides in an incredibly short time, thanks to the enthusiasm of local archæologists and the insight with which they have applied and adapted to local conditions the lessons of European archæology. When, however, the survey now initiated has been completed and its results, whatever they may be, have been made available for correlation with those of analogous studies in other parts of the world, where the records of pluviation and glaciation are being interpreted and brought into relation, the study of prehistory at large will be deeply indebted to the Government of the Union of South Africa for its public-spirited promotion of this investigation while opportunity still served, and to the South African Association for the Advancement of Science for its services to research in urging upon the Government the desirability of an undertaking which not only will promote understanding of the conditions of a problem of the first importance in human history, but also holds out every promise of being of crucial influence in the future of prehistoric studies.

\section{Sign Language as a Form of Speech}

In his Friday evening discourse at the Royal Institution on December 13, Sir Richard Paget discussed "Sign Language as a Form of Speech". The clue to the relationship between bodily gestures and the gestures of the mouth which produce speech was given by Darwin in 1872-namely, in the sympathy of movement between man's hands and his mouth. Charles Dickens, thirty years earlier, in "Pickwick Papers", had noticed the same effect. The deaf mute sign language is natural and universal among deaf mutes of all countries. The Red Indians of North America had a similar language of signs by which they could all communicate. In 1929, William Tomkins published his "Universal Indian Sign Language", which described 700-800 signs. The sign language of the aborigines of North-West-Central Queensland was described by Walter E. Roth in 1897. Garrick Mallery, writing in 1881 on the Indian sign language, described also the sign language of the Neapolitans. $\mathrm{He}$ concludes that all these languages are only dialects of a single language - the gesture speech of mankind. Recently, the Russian Academy of Sciences has discovered a sign language, used by women only, in Russian Armenia-also a pictographic script, twelfth to seventeenth centuries, which in many instances illustrates the sign language. Mr. Ivan Sanderson has recently discovered a sign language in the Cameroons; but hitherto gesture languages have been largely ignored. Many people think any alteration of spoken language is sacrilege; actually, all spoken languages are still primitive and unsystematic. Sign language is capable of great development as a universal language. Abstract ideas can be expressed in signs exactly as in spoken language-namely, by metaphorical reference to concrete ideas. Signs-unlike words-can be quantitative as well as qualitative, and shapes can be signed by direct imitation. In experimenting with the development of a new sign language, the vocabulary has been based on C. K. Ogden's 'Basic English' (850 words), but a much shorter sign vocabulary will suffice.

\section{Archæological Museums}

THE problem of the preservation and proper display of archæological collections and the associated 'finds' from the excavation of archæological sites is discussed by the Editor of Antiquity in the December issue of that journal. Briefly stated, the points to which he directs attention are two : the restrictions of space which preclude display according to modern methods, and differentiation to meet the respective needs of the 'ordinary' man and the student; and secondly, the necessity of a better organisation and distribution of the archæological material available for exhibition. In connexion with the second point, he is clearly preoccupied with the position of the British Museum (Bloomsbury), and here, as he points out, the question of reorganisation and distribution involves legislation. Further comment on the allocation of space to archæological exhibits may perhaps be postponed, pending the publication of a promised article in Antiquity which will deal with museum buildings.

THFse questions, however, serve to remind us that there are other aspects of the museum problem, which inevitably must be discussed, if, and when, the organisation of collections and their exhibition come under consideration. How far will it be advantageous, for example, to attempt to define the function of the local (that is, locally owned or municipally owned) museums, or to draft some scheme of co-operation between them and the 
national collections, which would serve as the basis for a national system, in which museums of general cultural and archæological interest dovetailed with a grouping of auxiliary museums of localised or specialised function. That there is already a certain amount of co-operation, localisation and specialisation in action is, of course, well known. The university museums, having special functions, would have a special place in such a scheme. There is at present, in fact, a certain amount of specialisation as between the museums of the various universities, the PittRivers at Oxford being the most conspicuous example. In one direction the way has been pointed out by Dr. R. E. Mortimer Wheeler, in his address when declaring open the Bishop Hooper's Lodging as a folk museum at Gloucester on October 10 last. A report of his address and of the opening ceremony will be found in the Museums Journal of December. Dr. Wheeler's most suggestive remark was that pending, or the pessimist might say failing, the institution of a national folk museum, the local museum should set about the collection of the material of local folk culture before it is too late.

\section{English Instrument Making}

AT a meeting of the Newcomen Society held at the Science Museum on December 11, a paper by Dr. R. S. Clay and Mr. T. H. Court on "English Instrument Making in the 18th Century" was read. As is well known, Mr. Court has contributed largely to the collection of scientific instruments in the Museum. Some of these had been arranged on the lecture table, and during the reading of the paper Dr. Clay used them to illustrate his remarks. In the eighteenth century, he said, England was fortunate in having a number of men who were not merely instrument makers but also men of scientific knowledge. Moxon, Senex, Short, Dollond and Nairne were all fellows of the Royal Society, and they and others such as Benjamin Martin, George Adams and James Ferguson made advances in the construction of scientific instruments which placed English microscopes, telescopes, etc., in the forefront and caused them to be copied abroad. One important invention was that of Marshall, who introduced the method of grinding a large number of lenses together on a block with a spherical tool, another that of the method of drawing brass tubes on a steel mandrel by which tubes capable of sliding smoothly in one another for telescopes could be made. Cuff, it appears, first introduced an allbrass telescope as a commercial instrument. The invention of the achromatic lens by Dollond, the invention of the quadrant by Hadley, the improvement in dividing scales by Bird and Ramsden and the construction of reflecting telescopes by Short all contributed to the supremacy of the English instruments. The biographies of a few of the most famous instrument makers only are known. Short was one of the few who made money by his business ; a good many others were at various times made bankrupt. The outstanding men at the end of the century were Jesse Ramsden (1735-1800) and Edward Nairne (1726-1806).

\section{Dr. R. A. Millikan and the Earth's Magnetic Field}

Ever since the time of Gauss, it has been assumed that the intensity of the earth's magnetic field is practically symmetrical. When attempting to find out the nature and distribution of the cosmic rays, Dr. Millikan has discovered that we must seriously modify our ideas about the earth's field. According to a report by Science Service, Washington, D.C., Dr. Millikan in a paper read at a meeting of the National Academy of Sciences at Charlottesville, Va., stated that the magnetic field extends into space for at least 10,000 miles and that the magnetic intensity is stronger on the side of the earth opposite to America. There is a greater effect on the cosmic ray intensity from the north magnetic pole to the equator in the region of India than there is in comparable latitudes in America. The Department of Terrestrial Magnetism of the Carnegie Institution of Washington has compared the magnetic variations on the surface of the earth with Millikan's results determined by cosmic ray intensities. It concludes that the variations of magnetism extend many thousands of miles into space. The earth's field appears to be lopsided.

\section{A Standardisation of Inefficiency}

In the World Economic Survey just issued by the League of Nations instructive statistics are given of the world production of electrical energy. Taking the average annual issue from 1925 until 1929 as 100 , the issue in 1932 was 119 , in 1933 it was 125 and in 1934 it was 138. Perusal of the Survey shows that in no other branch of industrial activity has such rapid progress been made during this period of great depression. World Power of October, in commenting on this, points out that the manufacture of plant does not increase pari passu with the demand for electrical energy. Part of the lag may be due to the great advances made in generating efficiency as a result of industrial research. This may have inspired a policy of caution among buyers of plant, and so they may be chary of placing new orders. It may be advisable to correlate technical research and new orders for electrical development, if overseas countries continue to protect inefficient installations by obsolete standardisation regulations. World Power states that scientific investigation is likely to receive a severe setback because research work will lack a world market for the products it improves. A secondary boom tends to develop in the sheltered manufacturing industries abroad, which receive added protection from the depreciation of the exchange. A number of foreign countries with depreciated exchanges are adopting plant and equipment regulations which give results much inferior to those obtained by research and the best technical practice. There is in fact a tendency towards standardising inefficiency, and this discourages scientific research.

\section{Modern Physics}

OF the series of pamphlets recently issued in Paris by Messrs. Hermann et Cie under the title "Actualites 